\title{
THE HIMALAYAS AND NEPALESE AGRICULTURE
}

\author{
Shreeram Ghimire, MSc. Ag. Eco ${ }^{21}$
}

\begin{abstract}
Two third of Nepal's area is hills and mountains which is a source of perennial rivers with Himalayas origin having massive hydroelectricity potential to domestic needs and growing demand of neighboring countries. Accelerated lce melting both globally and within the country creates unusual events from the mountainous rivers if unmanaged causes colossal loss. Natural resource and biodiversity conservation being the prime concern of developmental activities needs effective implementation of existing legal provisions. Nepal can enjoy domestic and global open market by adopting the farming of niche products by utilizing its unique climate to harness comparative advantage.
\end{abstract}

Key Words: Himalayas, Ice melting, agriculture, economy

\section{Introduction}

Agriculture is the mainstay of Nepalese economy that provides about 38 percent share to national GDP and employing 66 percent of the total 25.3 million people. The average population growth rate is 2.25 percent whereas average annual economic growth rate is 2.8 percent. Of the total area, only 21 percent is cultivable of which irrigation is available for only 32 percent of the cultivable land (Nepal District Profile, 2006). Nepal gifted with water resources that boost up beautiful and natural perennial snow fed rivers, rivulets, streams originating from formidable, beautiful Himalayas, glaciers, lakes and mountain springs and fountain. The major river systems that drain the whole watershed system of the country are Koshi, Gandaki and Karnali that all are originating from the Himalayas. These rivers play a significant role not only in irrigation for the agri- farming but also for beautiful natural springs, lakes, and generating hydro-power across the country.

The Great Himalayas of Nepal deserve significant role for prospering Agriculture sector and ultimately provides strong base for whole economic system. Of the thirty one Himalayan peaks over 7,500m height of the world, twenty-two are located in Nepal Himalayas including eight of the world's fourteen highest peaks. The melting of ice on the Earth's ice cover is more in various places and at higher rates than at any time since record keeping began. Reports from around the world compiled by the World Watch Institute showed that global ice melting accelerated during the 1990s-which was also the warmest decade on record. It is the matter of challenge for global environmental and development perspectives.

\section{Objectives}

The main objective of the paper is to show the relationships between the Himalayan resources and agriculture and to flash the current situation on global ice melting and its effect on environment

\section{Global Ice Melting}

The Himalayan space as the earth's ice cover acts as a protective mirror, reflecting a huge quantity of solar heat back into space and keeping the planet cool. Present continuous loss of

\footnotetext{
${ }^{21}$ Agricultural Economist, Agribusiness Promotion and Statistics Division, MOAC, Singhdurbar, Email: srghimire@moac.gov.np
} 
the ice would not only affect the global climate, but would also raise sea levels and spark regional flooding, damaging property and endangering lives (Koji et al, 2006). Large-scale melting would also threaten key water supplies as well as alters the habitats of many of the world's plants and animal species and would disturb the balance in the global ecosystem.

A report from the recent scientific research says that the polar regions are warming faster than the planet as a whole and have lost large amounts of ice in recent decades. The Arctic sea ice has been shrunk by an estimated 6 percent between 1978 and 1996, losing an average area of 34,300 square kilometers (Sakai et al, 1996). Of the polar ice cover, the Antarctic ice, which averages 2.3 kilometers in thickness and represents some 91 percent of Earth's ice, is also melting. So far, most of the loss has occurred along the edges of the Antarctic Peninsula, on the ice shelves that form when the land-based ice sheets flow into the ocean and begin to float.

The Arctic sea ice has also thinned dramatically since the 1960s and 70s. Between this period and the mid-1990s, the average thickness dropped from 3.1 meters to 1.8 meters-a decline of nearly 40 percent in less than 30 years period. The worldwide ice melting is being prominent and is an environmental warning for the Global environmental concern. Some examples of global ice melting are given in the Annex 1.

\section{Nepal's Himalayas and Ice Melting}

The Himalayas that cover the range about $2400 \mathrm{kms}$ consist of youngest and highest mountain system of the world those envelopes the south facing area between the Indus and Brahmaputra rivers. About one third $(800 \mathrm{kms})$ of its central portion transverses Nepal and is known as the Nepal Himalayas. The three fourth of the land of Nepal is hill and mountain that consists of many beautiful Himalayan peaks, glaciers, lakes and attractive eco-tourism patches, thus Nepal is a tourist destination for hikers and mountain climbers. There are more than thirty Himalayan peaks having height over 7500 m, twenty-two of them lie in Nepal Himalayas including eight of the world's fourteen highest peaks of the world. The names of the Himalayas with their respective height are given in Annex 2.

All these Himalayan peaks are having the eco- tourism importance as well as fountain sources of the national watershed system of the country The Himalayan range within Nepal fits into a geographic pattern as the culmination of a series of parallel ranges. The main mountain region, represented by the eternal ranges, lies about $90 \mathrm{kms}$ north of the Mahabharat Lekh. The intervening space between the two parallel ranges is made up of the lower belt of the low hills (Pahar) and the higher belt of elevated ridges (Lekh) that provide the first intimation of the high snow continuous range but rather a chain of lofty ridges separated by deep gorges.

There is another mountain range in the western and central Nepal that defines the boundary between Nepal and China. This border range has elevations ranging from 5000 to $6000 \mathrm{~m}$ with comparatively less rugged relief but a harsh climate. Different geologists / Scientists have documented a report that Khumbu Glacier on Mount Everest has retreated more than five kilometers from the time when Edmund Hillary and Tensing Norgay conquered the world's highest peak in 1953 (Sakai et al, 1996). But scientists fear that these water supplies could eventually dry up as the glaciers melt due to global warming. Researchers have therefore installed an automatic weather station on the Himalayan Ngozumpa Glacier, the longest in Nepal.

It has been observed that melting rate of ice cliffs coincided approximately with the calculation based on the heat balance consideration. It was $7.2 \mathrm{~cm}$ day-' on average for cliffs with various directions during the monsoon season. The ice cliff melt amount reaches $69 \%$ of 
the total ablation at debris covered area, although the area of ice cliffs occupies less than $2 \%$ of the debris covered area (Sakai et al, 1996). It has been found that there is a significant melting occurred every year at one site (wet site), whereas no melt occurred at the second site because of its high elevation (Koji et al, 2006).

\section{Nepalese Mountain and Agricultural Economy}

As three fourth of the total land is covered with hills and mountains it holds many beautiful Himalayan peaks, glaciers, lakes and attractive eco-tourism patches. The main river system of the country has given the base of commercial agriculture with $32 \%$ irrigated land. Swift rivers flowing south through the Himalayas have massive hydroelectric potential to service domestic needs and growing demand from India. Only about $1 \%$ of Nepal's hydroelectric potential is currently tapped. Several hydroelectric projects, at Kulekhani and Marsyangdi, were completed in the early to late 1980s. In the early 1990s, one large public-sector project, the 'Kali Gandaki A' (144 megawatts-MW), and a number of private projects were planned; some have been completed. The 'Kali Gandaki A' has started commercial operation in August 2002. Privately financed hydroelectric projects currently in operation are the Khimti Khola (60 MW), Bhote Koshi (36 MW) and Chilime projects. The other notable hydro projects are Trisuli and Sunkoshi (Shrestha, 2005). Recently, government has initiated the formulation of big hydro projects like Upper Karnali and Arun 3.

The country has a great variety of topography that is reflected in the diversity of weather and climate. The country experiences sub tropical to temperate climate within a very limited range of geographical distance. Major cereals crops are grown in terai, vegetables, fruits and livestock are grown in hills, livestock, temperate fruits and medicinal herbs are grown in mountains and upper valleys. Though agricultural growth rate is slightly higher than population growth rate, population pressure on natural resources is increasing. Nepal ranks among the world's poorest countries with a per capita income of around $\$ 300$. The country has, however, made progress toward sustainable economic growth since the 1950s and is committed to a program of economic liberalization. Capitalizing the diversified climatic condition and natural resources, Nepal can enter into the global competitive and open market with its identified niche products.

\section{Impact of Global Warming on Environment}

Melting of Ice everywhere is continuous at an accelerating rate. Rising global temperatures are lengthening melting seasons, thawing frozen ground, and thinning ice caps and glaciers that in some cases have existed for millennia. These changes are raising sea level faster than earlier projected by scientists, and threatening both human and wildlife populations (Sakai et al, 1996).

Melt water on top of glaciers and ice sheets contributes to fracturing and destabilization of the ice masses and increases flow rates as the water lubricates the underside of the ice. Increased fresh water from melting glaciers and sea ice could alter ocean circulation patterns and destabilize regional climate patterns and warmer waters may also decrease the ocean's ability to act as a carbon sink. If no action is taken to halt global warming, these positive feedbacks could quickly send climate change spiraling out of control (Kayastha et al, 2002).

The melting of Earth's ice cover would significantly alter the global climate-though the net effects remain unknown. Ice, particularly polar ice, reflects large amounts of solar energy back into space, and helps keep the planet cool. When ice melts, however, this exposes land and water surfaces that retain heat-leading to even more melt and creating a feedback loop that accelerates the overall warming process (World Watch Institute, 2000). 
Rapid glacial melting can also cause serious flood damage, particularly in heavily populated regions such as the Himalayas. In Nepal, a glacial lake burst in 1985, sending a 15-meter wall of water rushing 90 kilometers down the mountains, drowning people and destroying houses. A second lake near the country's Imja Glacier has now grown to 50 hectares, and is predicted to burst within the next five years, with similar consequences (Fujita et al, 2006).

Large-scale ice melt would also raise sea levels and flood coastal areas, currently home to about half the world's people. Over the past century, melting in ice caps and mountain glaciers has contributed on average about one-fifth of the estimated 10-25 centimeters global sea level rise-with the rest caused by thermal expansion of the ocean as the Earth warmed (World Watch Institute, 2000).

But ice melt's share in sea level rise is increasing, and will accelerate if the larger ice sheets crumble. Antarctica alone is home to 70 percent of the planet's fresh water, and collapse of the West Antarctic Ice Sheet (WAIS), an ice mass the size of Mexico, would raise sea levels by an estimated 6 meters-while melting of both Antarctic ice sheets would raise them nearly 70 meters (Kayastha et al, 2002).

There is a correlation between ozone levels and atmospheric temperature. The ozone layer depletion in the atmosphere is being a serious environmental concern that changes on a seasonal basis and is at its lowest levels in January, during Antarctic spring. Ozone levels are measured in Dobson units, a measurement of the thickness of pure ozone at normal sea level temperature and pressure. Thus, $100 \mathrm{DU}$ equals $1 \mathrm{~mm}$. of pure ozone at sea level (Murray, 2005).

\section{Causes and Sources of the Impact}

Severe deforestation in Nepal has led to shortages of animal fodder and firewood. In response to this concern, Forestry Volunteers work with the District Forest Offices to promote the equitable and proper management of scarce forest resources. They help establish and train forest user groups, assist in reforestation efforts, and work with schoolchildren to increase their knowledge of the environment (Fujita et al, 2006).

The means to predict ablation of snow and ice on glacier zed basins in the Himalayas is important in order to predict the long-term availability of water resources and assess response of climate change. Since the glacio-hydrological data are very scarce in high mountain areas, degree-day method is used to calculate snow/ice melting using monthly air temperature and precipitation data observed in or nearby the basin (Sakai et al, 1996).

Due to the accelerated ice melting along with the heavy rainfall, Nepal experienced a considerable quantity of fertile soil loss annually. Average of $30 \mathrm{mt}$ soil per hectare per year is being lost, of which $0.48 \mathrm{mt}$ in irrigated terrace, $1.86 \mathrm{mt}$ in grassy land, $2.7 \mathrm{mt}$ in upland, and $25 \mathrm{mt} / \mathrm{ha} / \mathrm{yr}$ soil has been lost in jungle areas (Land Slide run off and Soil Loss, Middle Hills, Nepal, 2005 -(website: www.gma.org/surfing/human/melting.html )

\section{Existing Legal Provisions and Their Implementation Status}

For capitalizing the existing and potential natural resources for the optimum exploitation for sustainable human utilization and environmental protection, Government of Nepal has formulated and made effective more than twenty policies, acts and regulations. The name details of the legal documents are given in Annex 3. (Alphabetical Omnium Gatherum of Acts, 2006).

In spite of the above mentioned legal provisions adopted by the state, their effective implementation aspect is weak. Various laws are overlapping and cross cutting among them. A 
variety of interventions are currently taking place towards biodiversity conservation and environment protection. Nepal has already set aside over 18 percent of its territorial areas as National Parks, Wildlife Reserves, Hunting Reserves and Conservation Areas. Recent government policies for natural resource management are geared towards integrating people in conservation endeavors. Biological diversity of protected areas will be increasingly managed with the help of local people with equitable benefit sharing philosophy. Conservation of nature and natural resources has been identified as a priority area in the then constitution of the Kingdom of Nepal (1990). The Government of Nepal therefore recognizes the significance of $\mathrm{CBD}$ to achieve sustainable development.

\section{Conclusion}

More than two third geographical areas is covered by mountains and hills in Nepal and it has only $21 \%$ land cultivable. Accelerated Ice melting both globally and within the country creates unusual current in the mountainous rivers and/if unmanaged causes huge economic loss. The country's diversified topography is reflected in the diversities of weather and climate. Agriculture sector is Nepal's principal economic area, employing over $66 \%$ of the population and providing $38 \%$ of GDP. Over growing population particularly in urban and semi urban valley, resulting in the depletion of forest cover for crops, fuel and fodder, and contributing to erosion and flooding in the areas. Perennial rivers with Himalayas origin have massive hydroelectric potential. Effective implementation of the existing legal provisions and judicial management of the domestic empire natural resources for sustainable economic development of the country is prerequisite of the future developmental programs. In the present open market economic era, country can benefit on producing identified niche products by capitalizing the diversified climatic condition and natural resources, and can withstand into the global competitive international market.

\section{REFERENCES}

1. Alphabetical Omnium Gatherum of Acts. (in Nepali) 2005, Saman Prakashan, Kathmandu, Nepal.

2. Fujita, Koji. 2006, Journal Of Geophysical Research, Vol. 111, D03109, Doi:10.1029/2005jd005894, 2006

3. Kayastha, R.B; Ageta, Y; Fujita, K. 2002, Use of Positive Degree-day Method For Calculating Snow/ice Melting and Discharge From Glacierized Basins In Nepal

4. Murray, D. 2005, Arctic Climate Impact Assessment. Earth Policy Institute, World watch Institute, WWF, NASA, National Snow and Ice Data Center

5. (www.gma.org/surfing/human/melting.html)

6. Nepal District Profile, 2006, Nepal Development Information Institute, Kathamndu, Nepal.

7. Nepal, Govinda, 2006, Development Planning in the Era of Globalization. Himalaya Book Stall, Kathmandu, Nepal.

8. Sakai A., Nakawo M. and Fujita K, 1996, Melt Rate of Ice Cliffs on the Lirung Glacier, Nepal Himalayas

9. Shrestha, S.H. 2005, Nepal in Maps. Educational Publishing House, Kathmandu, Nepal.

10. Web site of the World Watch Institute, March 6, 2000.

11. Land Slide run off and Soil Loss, Middle Hills, Nepal, 2005 -(website ) 
Annex 1 Ice Melting on Earth Cover

\begin{tabular}{|c|c|c|}
\hline Name & Location & Measured Loss \\
\hline $\begin{array}{l}\text { Arctic } \\
\text { Sea Ice }\end{array}$ & Arctic Ocean & $\begin{array}{l}\text { Has shrunk by } 6 \text { percent since } \\
1978, \text { with a } 14 \text { percent loss of } \\
\text { thicker, year-round ice. Has } \\
\text { thinned by } 40 \text { percent in less } \\
\text { than } 30 \text { years. }\end{array}$ \\
\hline $\begin{array}{l}\text { Greenland } \\
\text { Ice Sheet }\end{array}$ & Greenland & $\begin{array}{l}\text { Has thinned by more than a } \\
\text { meter a year on its southern } \\
\text { and eastern edges since } 1993 \text {. }\end{array}$ \\
\hline $\begin{array}{l}\text { Columbia } \\
\text { Glacier }\end{array}$ & $\begin{array}{l}\text { Alaska, } \\
\text { United States }\end{array}$ & $\begin{array}{l}\text { Has retreated nearly } 13 \\
\text { kilometers since } 1982 \text {. In } 1999 \text {, } \\
\text { retreat rate increased from } 25 \\
\text { meters a day to } 35 \text { meters per } \\
\text { day. }\end{array}$ \\
\hline $\begin{array}{l}\text { Portage } \\
\text { Glacier }\end{array}$ & Alaska & $\begin{array}{l}\text { Retreated more than } 3 \\
\text { kilometers between } 1990 \text { and } \\
1996, \text { compared with only half a } \\
\text { kilometer during the } 19^{\text {th }} \\
\text { century. Between } 1900 \text { and } \\
1996 \text {, rate of retreat increased } \\
10 \text {-fold. All } 15 \text { glaciers in the } \\
\text { vicinity are now retreating. }\end{array}$ \\
\hline $\begin{array}{l}\text { Gulkana } \\
\text { Glacier }\end{array}$ & Alaska & $\begin{array}{l}\text { Thinned by nearly } 5 \text { meters } \\
\text { between } 1989 \text { and } 1995 .\end{array}$ \\
\hline $\begin{array}{l}\text { Antarctic } \\
\text { Sea Ice }\end{array}$ & Southern Ocean & $\begin{array}{l}\text { Ice to the west of the Antarctic } \\
\text { Peninsula decreased by some } 20 \\
\text { percent between } 1973 \text { and } \\
1993 \text {, and continues to decline. }\end{array}$ \\
\hline Pine Island Glacier & West Antarctica & $\begin{array}{l}\text { Grounding line (where glacier } \\
\text { hits ocean and floats) retreated } \\
1.2 \text { kilometers a year between } \\
1992 \text { and } 1996 . \text { Ice thinned at a } \\
\text { rate of } 3.5 \text { meters per year. }\end{array}$ \\
\hline $\begin{array}{l}\text { Antarctic } \\
\text { Ice Shelves }\end{array}$ & Antarctic Peninsula & $\begin{array}{l}\text { Overall, have lost about } 8,000 \\
\mathrm{~km}^{2} \text { to date }\end{array}$ \\
\hline
\end{tabular}

Source: Compiled by Danielle Murray, Earth Policy Institute, February 2005, from sources including World Watch Institute, WWF, Arctic Climate Impact Assessment, NASA, National Snow and Ice Data Center.

Annex 2 Nepalese Himalayas with height more than $8000 \mathrm{mt}$

\begin{tabular}{|l|l|c|}
\hline S.N & Name of the Himalayas & Height \\
\hline 1 & Sagarmatha (Mt. Everest) & $8,848 \mathrm{~m}$ \\
\hline 2 & Kanchenjunga & $8,586 \mathrm{~m}$ \\
\hline
\end{tabular}




\begin{tabular}{|l|l|c|}
\hline 3 & Lhotse & $8,516 \mathrm{~m}$ \\
\hline 4 & Makalu & $8,463 \mathrm{~m}$ \\
\hline 5 & Cho Oyu & $8,201 \mathrm{~m}$ \\
\hline 6 & Dhaulagiri & $8,167 \mathrm{~m}$ \\
\hline 7 & Manaslu & $8,163 \mathrm{~m}$ \\
\hline 8 & Annapurna & $8,091 \mathrm{~m}$ \\
\hline
\end{tabular}

Annex 3 List of the Nepalese Laws and Policies related to Natural Resource Management (NRM)

1. Tourism Act, 2035

2. Travel and Trekking Rules and Regulations, 2062

3. Mountaineering Rules and Regulations, 2059

4. Hotel/Lodge/Restaurant and Bar Rules and Regulations, 2038

5. Rafting Rules and Regulations, 2063

6. Immigration Act, 2049

7. Immigration Rules and Regulations, 2051

8. Industrial Enterprises Act, 2049

9. Foreign Investment and Technology Transfer, 2052

10. Environment Protection Act, 2053

11. Environment Protection Regulation,

12. National Parks Regulation

13. Conservation Areas Regulation

14. Company Act, 2053

15. Agriculture Policy, 2061

16. Agribusiness Promotion Policy, 2064

17. Seed Act, 2045

18. Plant Protection Act, 2063

19. Information Technology Policy

20. Science and Technology Policy

21. Electronic Transaction Rules, 2005

22. Bio-Technology Policy, 2005

23. Third National Report for UNCCD

24. Environment Impact Assessment (EIA) 